5 Hsu CT, Yeh C, Cheng HH. Helicobacter pylori, gastritis and duodenitis in the healing process of duodenal ulcer. F Formos Med Assoc 1992; 91: 81-4.

6 Uyub AM, Raj SM, Visvanathan R. Nizam M, Aiyar S, Anuar AK. Helicobacter pylori Anfection in North-eastern Peninsular Malaysia. Scand $\mathcal{f}$ Gastroenterol 1994; 29: 209-13.

7 Chandrakumaran K. Duodenal ulcer, Helicobacter pylori and gastric secretion [PhD Thesis]. London University, 1991.

\section{Cancer of the oesophagus}

EDITOR,-In the absence of controlled trials of the treatment of oesophageal cancer several authors have turned to descriptive studies to investigate the survival of patients with this condition. ${ }^{1-4}$ The most recent of these was reported by Sagar et al (Gut 1994; 35: 941-5). While agreeing with several points made in this paper, we were disappointed that it failed to set their results, based on an audit of patients treated at the General Infirmary at Leeds, in the context of other published studies.

The Table summarises the results of those descriptive studies based in the United Kingdom and published since 1980. Although varying in location and time, each has attempted to avoid the biases of selective case series by reporting the results, after treatment, of all cases diagnosed within a given period from a defined population.

The results of these studies show considerable consistency, and three important points regarding surgery are apparent: surgical resection has poor longterm survival, high early mortality, and is performed in only a few of all patients presenting with oesophageal cancer. Surgery offers the prospect of 'cure' (if taken as five year survival) to less than $3 \%$ of all patients presenting and is irrelevant to those $60-80 \%$ of patients felt unsuitable for operation. Any argument that surgery should be considered in more patients must face up to postoperative death figures that can amount to a third of patients.

Taken together we feel these studies strongly reinforce the 'nihilistic' view of surgery for oesophageal cancer referred to by Sagar et al. If resection is being performed chiefly for symptomatic palliation then it must prove itself on those terms against cheaper and less invasive techniques, such as endoscopic intubation or laser recanalisation.

Surgery can offer cure for oesophageal cancer, but we should recognise that, with the current pattern of disease staging at presentation, this applies to a much smaller proportion of patients than the $20-40 \%$ currently being offered surgical resection. We support the call by Sagar et al (also voiced in the 1993 NCEPOD report ${ }^{5}$ ) for oesophagectomy to be carried out by specialist surgeons, however we feel their priority must be the better selection of cases not the treatment of more patients.
Equal priority must be given to setting up proper trials of the increasing number of palliative treatments offered to those unsuitable for surgery, who are currently the majority in the United Kingdom.

$S$ E OLIVER Department of Public Health Medicine, and Epidemiology, University Hospital, Queen's Medical Centre, Nottingham NG7 $2 U H$

1 Matthews HR, Waterhouse JAH, Powell J, McConkey CC, Robertson JE, eds. Clinical cancer monographs. Vol 1. Cancer of the oesophagus. Basingstoke: Macmillan, 1987.

2 Sagar PM, Gauperaa T, Sue-Ling H, McMahon MJ, Johnston D. An audit of the treatment of cancer of the oesophagus. Gut 1994; 35: 941-5.

3 Desa L, Raghunath AS, Chawla SL, Peel ALG, Dellipiani AW. Treatment policy for the management of carcinoma of the oesophagus. Br ₹ Surg 1988; 75: 275-8.

4 Oliver SE, Robertson CS, Logan RFA. Oesophageal cancer: a population-based study of survival after treatment. Br $\mathcal{F}$ Surg 1992; 79: 1321-5.

5 Campling EA, Devlin HB, Hoile RW, Lunn JN Report of the National Confidential Enquiry int Perioperative Deaths 1991/1992. London: National Confidential Enquiry into Perioperative Deaths, 1993: 115.

\section{Reply}

EDITOR,-I read with interest the comments of Drs Oliver and Logan and am grateful for the opportunity to reply.

Their Table shows the similarity in outcome of four United Kingdom studies. We chose not to set our results in the context of United Kingdom studies alone but referred instead to the excellent review of 130 series in the world medical publications by $\mathrm{Dr}$ Muller. ${ }^{1}$

We did not advocate a need to simply increase the numbers of patients undergoing oesophagectomy but rather implied a need for more patients with cancer of the oesophagus to be adequately considered for surgical resection and agree that careful selection of cases is essential. University Department of Surgery Royal Liverpool University Hospital Prescot Street Liverpool L7 $8 X P$

1 Muller JM, Erasmi H, Stelzner M, Zieran U, Pichlmaier H. Surgical therapy of oesophageal carcinoma. Br $\mathcal{F}$ Surg 1990; 77: 845-57.

\section{Current concepts in metastasis}

EDITOR,-The progress report (Gut 1994; 35: 996-1000) provides a concise and instructive overview of the role of adhesion molecules in invasion and metastasis. Metastasis is viewed as an evolutionary process entailing the sequential selection of subclones with increasingly aggressive characteristics. This concept has been promulgated mainly on the basis of in vitro and animal models utilising cell lines. Extrapolating these experimental findings to the clinic may lead to conceptual inaccuracies. For example, taking colorectal cancer as the model, is it certain that metastases represent subclones that can be distinguished genetically from the primary tumour? Colorectal cancers show remarkable stability in their morphological and phenotypic characteristics with time. Liver metastases appearing years after removal of the primary may be indistinguishable from the primary. Indeed the same heterogeneity that is seen in the primary may be echoed in the secondary deposits. $^{1}$ Are there really multiple cell populations or are we overinterpreting examples of transient epigenetic modulation?

The period in the evolution of colorectal cancer in which there is undoubted subclonal selection is in the stepwise conversion of a normal cell to a cancerous cell through the intermediate stage of an adenoma. The outcome may be a well, moderately or poorly differentiated cancer with a metastatic potential that can be correlated with the grade of differentiation. However, evidence for the further selection of metastatic subclones, at least with respect to colorectal cancer, is lacking.

Department of R JASS School of Medicine, iversity of Auckland Private Bag 92019 Private Bag 92019,
Auckland, New Zealand

1 Jass JR, Mukawa K, Richman PI, Hall PA. Do aggressive subclones within primary colorectal cancer give rise to liver metastases? Int $\mathcal{f}$ Colorect Dis 1989; 4: 109-17.

\section{NSAIDs and the chemoprevention of colon and oesophageal cancer}

EDITOR,-I read with interest two articles in Gut. Drs Choi and Zelig (1994; 35: 950-4) show that ulcerative colitis and Crohn's disease are pre-neoplastic colorectal lesions with similar clinicopathological features while Manzano et al (Gut 1994; 35: 955-60) illustrate that ulcerative colitis is associated with $\mathrm{T}$ lymphocyte immunosuppression. Choi and Zelig suggest a potential for nonsteroidal anti-inflammatory drugs (NSAIDs) as a chemopreventive measure in patients with inflammatory bowel disease on the basis that chronic inflammation is carcinogenic. I write to expand on this suggestion given the data of Manzano et al.

Epidemiological studies have shown that the regular consumption of the NSAID aspirin is associated with a reduced risk of

Descriptive studies of oesophageal cancer treatment (in the UK) published since 1980

\begin{tabular}{|c|c|c|c|c|c|c|c|c|c|c|c|c|}
\hline \multirow{3}{*}{\multicolumn{3}{|c|}{ Study details }} & \multicolumn{4}{|c|}{ Surgical resection } & \multirow{2}{*}{\multicolumn{2}{|c|}{ Radiotherapy }} & \multirow{2}{*}{\multicolumn{2}{|c|}{ Intubation }} & \multirow{2}{*}{\multicolumn{2}{|c|}{ No treatment }} \\
\hline & & & \multirow[b]{3}{*}{ No (\%) } & \multirow{2}{*}{\multicolumn{2}{|c|}{$\begin{array}{l}\text { Survival } \\
\text { rate }^{\star}(\%)\end{array}$}} & \multirow{3}{*}{$\begin{array}{l}30 \text { Day } \\
\text { mortality } \\
(\%)\end{array}$} & & & & & & \\
\hline & & & & & & & \multirow[b]{2}{*}{ No (\%) } & \multirow{2}{*}{$\begin{array}{l}\text { Median } \\
\text { survival } \\
\text { (day) }\end{array}$} & \multirow[b]{2}{*}{ No (\%) } & \multirow{2}{*}{$\begin{array}{l}\text { Median } \\
\text { survival } \\
\text { (day) }\end{array}$} & \multirow[b]{2}{*}{ No (\%) } & \multirow{2}{*}{$\begin{array}{l}\text { Median } \\
\text { survival } \\
\text { (day) }\end{array}$} \\
\hline $\begin{array}{l}\text { Time period } \\
\text { covered }\end{array}$ & Location & No & & 1 Year & 5 Year & & & & & & & \\
\hline $\begin{array}{l}1956-1976 \\
1975-1988 \\
1976-1986 \\
1982-1985\end{array}$ & $\begin{array}{l}\text { W Midlands } \\
\text { Leeds }^{2} \\
\text { N Tees } \\
\text { Nottingham }^{4}\end{array}$ & $\begin{array}{r}4680 \\
316 \\
120 \\
268\end{array}$ & $\begin{array}{r}1104(24) \\
134(42) \\
21(18) \\
92(35)\end{array}$ & $\begin{array}{l}36 \\
40 \\
38 \\
41\end{array}$ & $\begin{array}{r}11 \\
7 \\
10 \\
2\end{array}$ & $\begin{array}{c}32 \\
27 \\
14 \\
9 \dagger\end{array}$ & $\begin{array}{c}725(16) \\
29(9) \\
19(16) \\
35(13)\end{array}$ & $\begin{array}{l}\text { NA } \\
175 \\
\text { NA } \\
190\end{array}$ & $\begin{array}{r}1002(21) \\
64(20) \\
57(48) \\
106(40)\end{array}$ & $\begin{array}{l}\text { NA } \\
106 \\
167 \\
100\end{array}$ & $\begin{array}{r}1581(34) \\
82(26) \\
16(13) \\
28(10)\end{array}$ & $\begin{array}{l}\text { NA } \\
91 \\
\text { NA } \\
21\end{array}$ \\
\hline
\end{tabular}

^Crude survival rates, fmortality during first hospital admission. NA $=$ not available. 